\title{
高温空気噴霧燃焼の可燃限界の解明
}

\section{Flammability limits of the spray HiTAC}

\author{
○学 前川 浩規（豊橋技科大） 正 名田 譲（徳島大院） \\ 正 伊藤 高啓（豊橋技科大） 正 野田 進（豊橋技科大）
}

\begin{abstract}
Hiroki MAEGAWA, Toyohashi University of Technology, 1-1 Hibarigaoka, Tempaku, Toyohashi, 441-8580, Japan Yuzuru NADA, The University of Tokushima, 2-1 Minamijyousanjima, Tokushima, 770-8506, Japan Takahiro ITO, Toyohashi University of Technology, 1-1 Hibarigaoka, Tempaku, Toyohashi, 441-8580, Japan Susumu NODA, Toyohashi University of Technology, 1-1 Hibarigaoka, Tempaku, Toyohashi, 441-8580, Japan
\end{abstract}

Key Words: HiTAC, flammability limit, liquid fuel, recirculation vortex

\section{1. 緒言}

バイオ燃料を用いた高温空気燃焼 ${ }^{[1]}$ は, $\mathrm{NOx}$ と $\mathrm{CO}_{2}$ の排出量 削減を同時に達成可能な燃焼技術である. バイオ燃料として液 体燃料であるバイオディーゼル燃料や植物油を考えると, 液体 燃料を用いた高温空気燃焼の NOx 排出特性や燃焼を維持でき る条件, すなわち可燃限界について把握する必要がある. 以前 の研究において, 高温空気燃焼の可燃限界は, Well-stirred reactor の火炎構造に基づく可然限界 ${ }^{[2]}$ や，浮き上がり火炎の吹き飛び 限界 ${ }^{[3]}$ とて予測されている。 しかし, これらの研究は気体燃 料を用いた高温空気燃焼を対象としており，液体然料を用いた 場合の可然限界に関する研究はほとんど行われていない．本研 究では, 液体燃料を用いた高温空気燃焼の可燃限界の予測方法 を確立するために, 高温空気噴霧燃焼の可燃限界を明らかにし， 燃焼形態との関係について検討した.

\section{2. 実験装置および測定方法}

図 1 に実験炉の模式図を示す。実験炉は高さ $1000 \mathrm{~mm}$, $200 \mathrm{~mm} \times 200 \mathrm{~mm}$ の矩形断面を有する小型燃焼炬である．炉底中 央の二流体噴霧ノズル（BIMJ2004，いけうち）から，液体然料 が圧搾空気とともに炬内に噴霧される.噴霧ノズルの両側には, 内径 $8 \mathrm{~mm}$ の酸化剂ノズルが設置されている．噴霧ノズルと酸 化剂ノズルの間隔は $60 \mathrm{~mm}$ である. 炉内には壁面に沿って外径 $6 \mathrm{~mm}$ のステンレス製冷却管が設置されており，最大 $2.3 \mathrm{~kW} の$ 熱損失を与えることができる.

燃料には灯油を用いており，燃料流量は全ての条件で $0.571 / \mathrm{h}$ 一定とした。レーザー回折法による簡易粒径計測装置 ${ }^{[4]}$ を用 いて燃料液滴の粒径を計測した結果, 燃料液滴のザウテル平 均粒径は $41.0 \mu \mathrm{m}$ であった。酸化㓮はノズル直下に設置された ヒーターによって最高 $1023 \mathrm{~K}$ まで予熱され, 炉内に投入される. 酸化剂は空気と窒素の混合気であり, 酸化剂の酸素濃度 $X_{\mathrm{O} 2}$ は $21 \%$ から $9 \%$ とした。酸化剂と圧搾空気を含めた総括当量比は 0.81 であり，圧搾空気の夕に対する当量比は 4.6 である.

本研究では，炉出口における一酸化炭素 $(\mathrm{CO})$ 濃度測定，炉出 口からの火炎の直接撮影と液滴の可視化，および炉内の温度お よび酸素濃度測定を行った。炉出口に挿入されたプローブによ

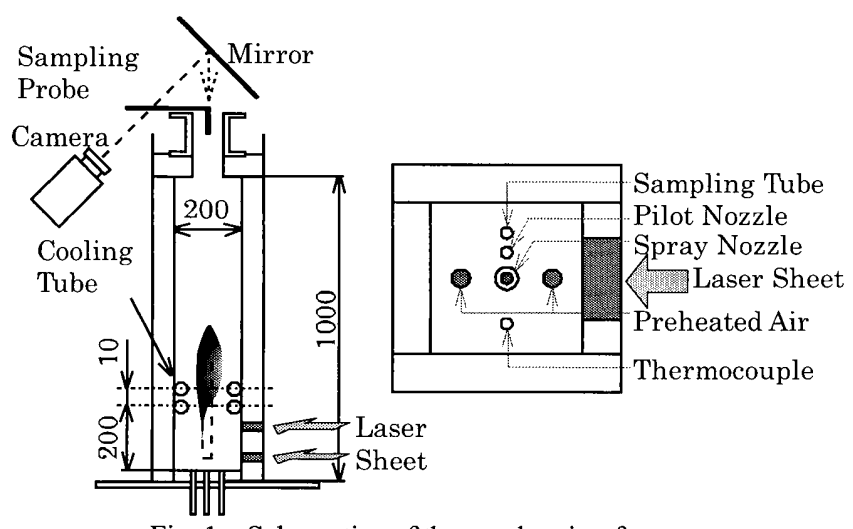

Fig. 1 Schematics of the combustion furnace.
り燃焼排ガスをサンプリングし，排ガス分析器 (CGX-7000, 島 津製作所）を用いて CO 濃度を測定した，本研究では，測定さ れた CO 濃度が 300ppm 超えた条件を可燃限界としている. 燃料液滴の可視化には Nd:YAG レーザー(GCR-170, Spectra-physics)を光源とする平面レーザー光を用いた。燃焼炬 右側の炉壁，炉底面から高さ $x=50 \mathrm{~mm}$ と $x=150 \mathrm{~mm}$ にレーザー 入射用の空が二つ設置されている. 可視化された液滴は, 炬出 口から CCD カメラ(SXC-ST51, SONY)により撮影される.

炬内火炎の燃焼形態を明らかにするために，金属線を用いた 炉内温度測定 ${ }^{[5] を}$ 行った。噴霧ノズル中心から $10 \mathrm{~mm}$ の位置に 直径 $0.1 \mathrm{~mm}$ の白金口ジウム線を鉛直方向に張り，その発光を炉 側壁の観察空から CCD カメラで撮影寸る.なお撮影は 10 秒閒, 30fps で行った. 白金ロジウム線の温度と発光強度の検定結果か ら，炉内の白金ロジウム線の温度分布を得ることができる.

過去の高温空気燃焼の研究から，炉内循環渦により上流側に 輸送される既然ガスの温度と酸素濃度が燃焼特性に強い影響を 与えることが明らかにされている ${ }^{6]}$. 循環渦により運ばれる既 燃ガスの温度と酸素濃度の測定は，噴霧ノズルの両側 $60 \mathrm{~mm} の$ 位置に熱電対（R 型）とサンプリングプローブを $50 \mathrm{~mm}$ 炉内に 挿入することにより行われた。

\section{3. 実験結果および考察}

図 2 に実験から得られた可然限界を示す， $T_{\mathrm{a}}$ と $X_{\mathrm{O} 2}$ は，それ ぞれ酸化剂ノズル出口における酸化剤温度と酸素濃度を示して いる．図中の線は可燃限界を示しており，線より下の条件では 火炎は維持されず，不完全燃焼を起こす， $Q_{\text {out }}$ は炉内に設置さ れた冷却管による熱損失量を示している。本研究では， $T_{\mathrm{a}}=1023 \mathrm{~K}$ から $100 \mathrm{~K}$ ずつ予熱温度を下げていき，可燃限界を調 査した。このため, 図 2 に示す可燃限界は CO 濃度が $300 \mathrm{ppm}$ 以上となる条件よりも $100 \mathrm{~K}$ 予熱温度の高い条件である。予熱 温度を下げるに従い,ノズルに付着した火炎, 浮き上がり火炎, 明確な輪郭を持つ火炎が数秒每に発生する状態（間欠火炎）の 三つが確認された．実験条件が可燃限界に近づくに伴い，炉内 の火炎形態は付着火炎から間欠火炎へ遷移寸る。

冷却管による熱損失が無い場合 $\left(Q_{\text {out }}=0 \mathrm{~kW}\right), X_{\mathrm{O} 2}>12 \%$ では 酸化剂が常温においても, パイロット燃料無しで然焼を維持で きている．この場合，炉内の循環渦により上流に輸送された高

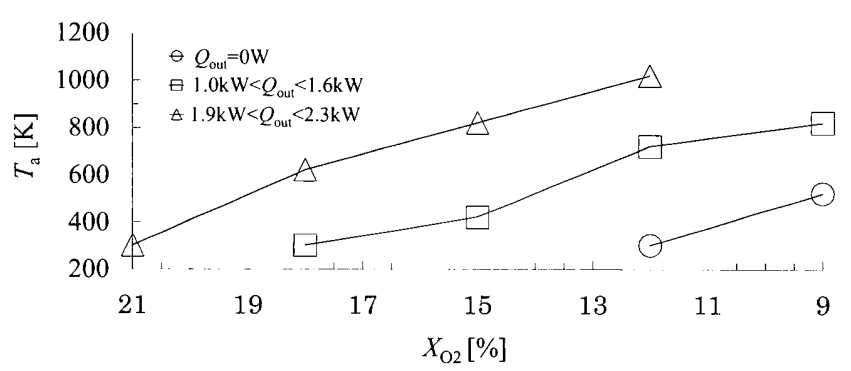

Fig. 2 Flammability limits of the spray HiTAC with respect to preheat temperature and $\mathrm{O}_{2}$ concentration in oxidizer flows. 


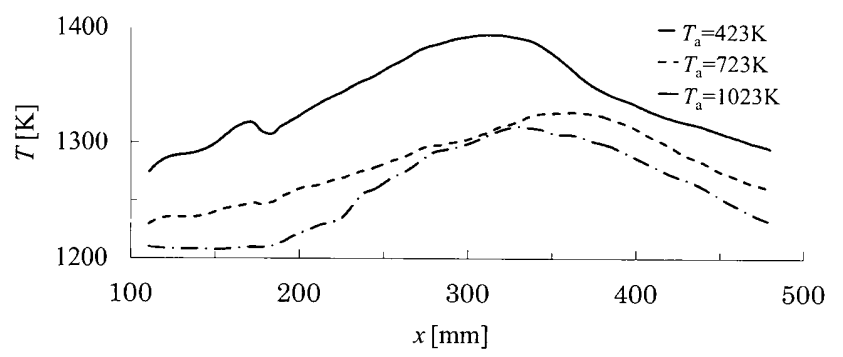

Fig.3 Axial distributions of the mean temperature $\left(X_{\mathrm{O} 2}: 15 \%\right)$.

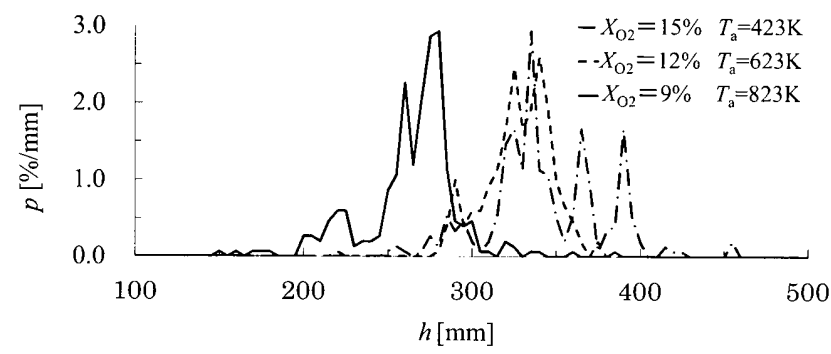

Fig.4 Probability density functions of the flame location.

温既燃ガスが着火源になると考えられる. 熱損失量の増加に伴 い, 可燃限界が高温かつ高酸素濃度側へ移動し，可燃範囲は狭 くなる．冷却管を挿入した場合，循環渦により運ばれる高温既 燃ガスを直接冷却することとなる。このため，着火源となる既 燃ガスの温度が低下し可然範囲が狭くなったと考えられる。ま た, 液滴の可視化結果から, 熱損失量の増加に伴い液滴の到達 距離が長くなることがわかった（図示せず）。これは，液滴周 囲の既燃ガスの温度の低下により，燃料の蒸発速度が低下した

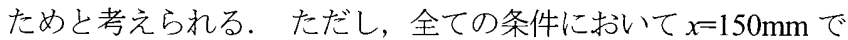
は液滴が観察されなかったことから，液滴の存在する範井は $x<150 \mathrm{~mm}$ である.

本研究で対象とした火炎は，浮き上がり火炎を経て消炎に至 る.このことから，浮き上がり高さは可燃限界を表わす重要な 指標となる，浮き上がり火炎に関する多くの研究[3]では，浮き 上がり高さは目視による観察から得られる。しかし，高温空気 燃焼の場合，火炎を目視で確認できない。このため，白金ロジ ウム線を用いた温度測定から火炎の位置を特定する. 図 3 に $X_{\mathrm{O} 2}=15 \%$ の条件における時間平均された炉内温度分布を示す. $X_{\mathrm{O} 2}=15 \%, T_{\mathrm{a}}=1023 \mathrm{~K}$ および $T_{\mathrm{a}}=723 \mathrm{~K}$ においては, 温度はノズル 近傍から直線的に上昇しており，付着火炎が生じていると考え られる. 一方，可燃限界条件である $X_{\mathrm{O} 2}=15 \%, T_{\mathrm{a}}=423 \mathrm{~K}$ におい ては, $x=250 \mathrm{~mm}$ 付近より急激な温度上昇がみられる。これは浮 き上がり火炎に対応寸ると考えられる。このことから，浮き上 がり火炎は液滴の存在する範囲 $(x<150 \mathrm{~mm})$ より下流に位置す ることがわかる，これは，可燃限界付近の火炎では，気体燃焼 が支配的であることを示している.

本研究では, 最高温度を示寸位置を火炎位置と定義し, 各時 刻における火炎位置を求めた。図 4 は, 火炎位置 $h$ の確率密度 関数 (PDF) を示している. 四示した条件は全て可然限界の条 件である. 最も存在確率の高い火炎位置は $h=280 \mathrm{~mm}$ から $h=340 \mathrm{~mm}$ である.これは, 可然限界の条件では，予熱温度およ び酸素濃度が異なるにも関わらずほぼ同じ火炎位置となること を示している.さらに, PDF の分布から, 火炎は $100 \mathrm{~mm}$ 程度 の幅で振動していることがわかる。

これらの測定結果より，火炎形態と可燃限界の関係について 次のように考える. 図 5 に火炎形態の変化を示す. 図 5(a)から (c)一の変化は, 酸化剤温度を低下させた場合の火炎形態の変化 に対応する，図中の矢印は，噴霧流と炉壁との間に形成された 循環渦を示す. 噴霧ノズルの噴霧角度から, 循環渦は $x<580 \mathrm{~mm}$

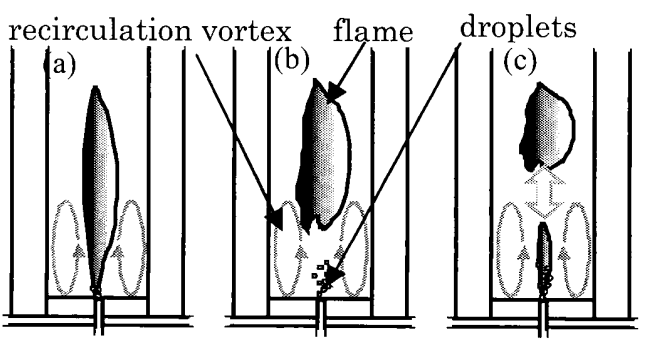

Fig. 5 Schematics of spray flames in the HiTAC furnace ((a) attached flame, (b) lifted flame, (c) pulsed flame).

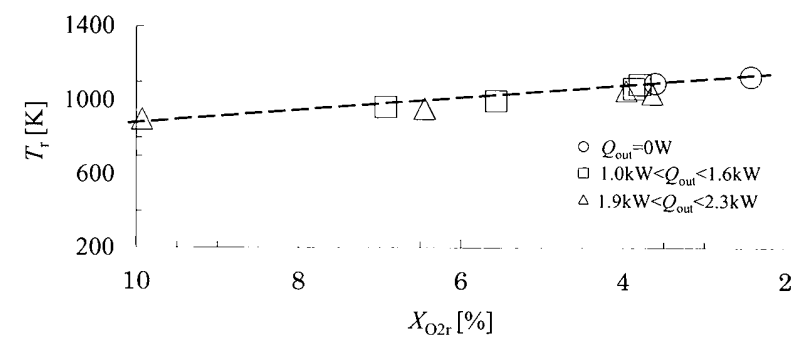

Fig. 6 Flammability limits of the spray HiTAC with respect to temperature and $\mathrm{O}_{2}$ concentration in the recirculation vortex.

に位置すると考えられる．循環渦中心から下流側では，既然ガ スは上流側に循環され，上流側では既然ガスは噴霧流に巻き込 まれる. 酸化剂予熱温度が十分に高い場合, 既燃ガスも高温と なる．循環された高温既燃ガスにより蒸発した燃料はノズル近 傍で着火し, 付着火炎が形成される.酸化剂予熱温度の低下は, 既然ガス温度の低下を招く。この結果，着火遅れ時間は長くな り, 浮き上がり火炎が形成される.さらに酸化剤温度が低下寸 ると, 浮き上がり高さは高くなる. 浮き上がり高さが渦中心よ り高くなった場合，燃料と酸化剂の未燃混合気が上流側に循環 される，未燃混合気は高酸素濃度である一方，その温度は非常 に低い, よって着火遅れは増大し, 燃焼形態は間欠火炎に遷移 し，消炎に至る.

上記の議論から，燃焼炉内の火炎の維持には，循環渦の温度 が重要になると考えられる.そこで図 2 に示される可然限界を, 循環渦により循環される既燃ガスの温度 $T_{\mathrm{r}}$ と酸素濃度 $X_{\mathrm{O} 2 \mathrm{r}}$ によ り整理する. 図 2 と異なり，可燃限界は熱損失量の変化によら ず 1 本の線で表現される.このことから, 循環渦の温度と酸素 濃度により可燃限界は表現できることがわかる。また，循環渦 の酸素濃度は最高 $10 \%$ に達している。これに対して，既然ガス の酸素濃度は完全然焼を仮定した場合，最高 $3.2 \%$ あるる. 循環 渦の酸素濃度は既燃ガスの酸素濃度より高い。これは, 循環渦 が既燃ガスだけでなく，末燃の酸化剂も上流側に輸送している ことを示している.これらの結果は，図５により示された火炎 形態と可然限界の関係を裹付けるものである.

\section{4. 結論}

本研究では，液体燃料を用いた高温空気燃焼におうる可燃限 界の予測方法を確立するために，小型燃焼炬を用いた実験を行 った.この結果，火炎は炉内循環渦により輸送される熱量の不 足により消炎に至る.この熱量の不足は，火炎浮き上がり高さ と炉内循環渦の位置関係により発生する。

\section{参考文献}

1. Katsuki, M.,et al., Proc. Combust. Inst., 27 (1998), pp. 3135-3146.

2. Plessing, T., et al., Proc. Combust. Inst., 27 (1998), pp.3197-3204.

3. Choi, B.C., Combust. Flame, 156 (2009), pp. 396-404.

4. 鈴木ら, 微粒化, 16 (2007), pp. 34-46.

5. 永野ら, 第 48 回燃焼シンポジウム講演論文集(2010), pp. 476-477.

6. 名田ら, 日本機械学会論文集 B編, 75 (2009), pp. 1870-1878. 